\title{
Quantitative Economic Evaluation of Zakah-Poverty Nexus in Kano State, Nigeria
}

\author{
Daud Mustafa \\ Federal University Dutsin-Ma (FUDMA), Nigeria, mdaud@fudutsinma.edu.ng/mdaud1431h@gmail.com \\ Abubakar Jamilu Baita \\ Yusuf Maitama Sule University, Nigeria,abubakarbaita@gmail.com \\ Hussaina Datijjo Adhama \\ Yusuf Maitama Sule University, Nigeria, hussainaadhama@gmail.com
}

Received: November 15, 2019 Revised: January 4, 2020 Accepted: January 7, 2020

Article History

\section{Abstract}

Nigeria is the largest economy in Africa and yet, a poverty-ridden oil-producing country. Thus, poverty remains a persistent macroeconomic challenge in Nigeria with devastating consequences, especially in the Muslim populated states like Kano. Surprisingly, Kano state, which is the most populated state in Nigeria with more than 15 million people, is one of the 14 most poverty-ridden states in Nigeria, despite the practice of Zakah institution (ZI). Therefore, this study empirically evaluates the revenue base and impacts of ZI on poverty alleviation in Kano state. Hence, 1,230 copies of questionnaires were administered and seven high profile Zakah payers were interviewed. Meanwhile, the data analysis was accomplished using descriptive statistics, correlation, and regression techniques, among others. The major findings indicate that the enormous revenue base of Zl for poverty alleviation exists, because of the significant Zakah payment by high ability Zakah payers. Similarly, ZI positively impacts on poverty alleviation. All in all, the findings lend credence to the Zakah-effectiveness hypothesis. Hence, this study recommends that Kano state government should exemplify more accountability and transparency in Zakah management. Moreover, a Ministry of Zakah and Hubusi Affairs should be established with the mandates of poverty alleviation and economic empowerment in the state.

Keywords: Nigeria, Poverty alleviation, Regression model, Zakah-effectiveness hypothesis, Zakah institution

JEL Classification: 057; 132; C21; Z12

@ IJIEF 2020 published by Universitas Muhammadiyah Yogyakarta, Indonesia All rights reserved

DOI:

https://doi.org/10.18196/ijief.2120
Web:

http://journal.umy.ac.id/index.php/ijief/article/view/7488

Citation:

Mustafa, D., Baita, A. J., \& Adhama, H. D. (2020). Quantitative Economic Evaluation of Zakah-Poverty Nexus in Kano State, Nigeria. IJIEF: International Journal of Islamic Economics and Finance, 3(1), 2150. DOI: https://doi.org/10.18196/ijief.2120 
Mustafa, Baita, \& Adhama $\mid$ Quantitative Economic Evaluation of Zakah-Poverty Nexus in Kano State, Nigeria

\section{Introduction}

\subsection{Background}

Nigeria is the largest economy in the African continent and the most populated black nation in the world. Also, Nigeria is the $11^{\text {th }}$ largest producer of petroleum in the world, the $8^{\text {th }}$ largest exporter of petroleum and the $10^{\text {th }}$ largest owner of proven oil reserves globally (Hadejia, 2017; Mustafa, Sabiu \& Bello, 2017a). Despite all these amiable socio-economic features, Nigeria is one of the poorest oil-producing countries with a wide array of unexploited mineral resources like natural gas, coal, gold, iron ore, tin, bauxite, tantalite, limestone, lead and zinc among others. Interestingly, the socio-political and economic characteristics of the country reveal a mixed economy with an emerging market and a federating unit of 36 states and Federal Capital Territory (FCT) - Abuja as the Federal capital. Nigeria is also made-up of two broad regions known as Northern and Southern regions (Hadejia, 2017; Mustafa et al., 2017a; Wali, 2013). In this connection, the consequences of under-exploitation and under-utilization of resources coupled with bad governance and dwindling oil revenue from the federation account are substantially responsible for the high level of poverty in Nigeria with Kano state - a major victim.

In this regard, Kano state which is serving as the state of interest in this study is the most populated in Nigeria with an estimated population of more than 15 million people and a Muslim majority of about 95\%. The state is the commercial nerve centre of the Northern region and even sub-Saharan Africa region with historic flourishing manufacturing and industrial sectors but which seem now to be in comatose. Surprisingly, Kano state is one of the 14 most poverty-ridden states in the country, despite her natural endowments and vibrant religious economic legacy like Zakah institution (ZI), waqf and hisbah, among others, which dates back to the $19^{\text {th }}$ century Dawlatul-Usmaniyyah - Sokoto Caliphate (1804-1903). Also, the state accounts for a high level of poverty of more than 70\% (Mustafa et al., 2017a; Wali, 2013). Nonetheless, the state represents Islamic religious front-liner in the practice of Islamic economic institutions like Zakah, which is a potent and sustainable Islamic social security measure for tackling poverty in Muslim economies like Kano state. It is, however, instructive to state that poverty is a universal socio-economic phenomenon that seems obvious in virtually all countries of the world including developed economies. It is assumed easier to comprehend but difficult to define due to academic and ideological leanings of the analysts.

Notwithstanding, it is generally agreed that poverty means a lack of basic needs and services like food, shelter, bedding, clothing, basic healthcare,

IJIEF: International Journal of Islamic Economics and Finance, 3(1), 21-50|22 
Mustafa, Baita, \& Adhama $\mid$ Quantitative Economic Evaluation of Zakah-Poverty Nexus in Kano State, Nigeria

and education, which implies a lack of minimum standard of living (Sadeq, 1990; Maidugu, 2002; Mustafa \& Adewale, 2014). Therefore, the conceptualization of poverty in this study is both human and income poverty in line with UNDP (2000) cited in Mustafa and Adewale (2014). As rightly noted by Ahmed (2004), Islam considers the improvement in the material well-being of man as having a direct positive impact on his spiritual wellbeing. This is even the fundamental reason why Islam places a lot of attention to poverty and the various poverty alleviation measures like the Zakah institution. Underscoring the efficacy and historical antecedent of Zakah institution as a potent and veritable measure for poverty alleviation in Muslim societies, Nadzri et al. (2012) submit that, "History proves that with proper management, zakat is capable to eliminate poverty" (p. 71).

In this direction, some studies have established a positive effect and significant link between both Zakah institution and poverty alleviation in Muslim societies. They also observed that Zakah potentials are yet to be fully tapped in Muslim countries, especially in Nigeria with Muslim population of over 90 million (Aliyu, 2002; Maidugu, 2002; Abdullahi, 2006; Amuda, 2013; Wali, 2013; Ibrahim, 2015; Mustafa \& Idris, 2015; Mustafa \& Maiyaki, 2011, 2016; Adamu \& Saad, 2016; Kefeli, Johari, Ahmad, Mohd Daud \& Shah Zaidi, 2017; Mustafa et al., 2017a among others). At this juncture, it is instructive to mention that the most populated state in Malaysia known as Selangor (with $6.38 \mathrm{~m}$ people as at 2017) realized RM13.8m as Zakah revenue in 1991 (equal to $\mathrm{A690m}$ ) and in 2010, the amount generated rose to RM336.8m (i.e. $\mathrm{A} 16.84$ billion by $\mathrm{A} 50$ exchange rate to RM1 as at 2010) (Mustafa et al., 2017a; Ab Rahman, Alias \& Syed Omar, 2012). Whereas the highest Zakah collection of $\mathrm{N} 16.14$ million was generated by the Kano State Zakah and Hubusi Commission in 2012, which later dropped to a miserable 66.54 million in 2015 (see Kano State Zakah and Hubusi Commission, 2004, 2006, 2010, 2015). As rightly noted in a conceptual and theoretical study by Mustafa et al. (2017a), the potentials to generate as much as $\mathrm{A} 25$ billion (i.e. US\$81.97m at N305 per US\$1) exists in Kano state if qualified Zakah payers of one million people (from a population of almost 15 million people) will pay $\mathrm{A} 25,000$ each from their zakatable cash of $\mathrm{A1}, 000,000$ only. This amount is certainly a huge sum for poverty alleviation if compared to the highest Zakah collection of $\mathrm{A} 16.14 \mathrm{~m}$.

IJIEF: International Journal of Islamic Economics and Finance, 3(1), 21-50|23 
Mustafa, Baita, \& Adhama $\mid$ Quantitative Economic Evaluation of Zakah-Poverty Nexus in Kano State, Nigeria

\subsection{Objective}

In this connection, this study empirically evaluates the revenue base and impacts of Zakah institution on poverty alleviation in Kano state. It also examines the Zakah-poverty alleviation nexus and ascertains whether prudent management of Zakah institution (ZI) has a positive influence on poverty alleviation in the state. As such, the hypotheses to be validated are H1: Zakah institution has an enormous revenue base for poverty alleviation in Kano state; H2: Zakah institution has positive impacts on poverty alleviation in Kano state; and H3: Prudent management of Zakah institution is germane for poverty alleviation.

\section{Literature Review}

\subsection{Background Theory}

\section{Theory of Obligation}

Among the theories of Zakah institution discussed by Al-Qardawi (2000) in his famous work on Figh az-Zakah is the theory of obligation. This theory states that Zakah is an obligatory act of worship like Salah, Sawm, and Hajj, among others. As such, Allah (SWT) who is the Sole Creator of man has the right to instruct His servants to perform any obligation in thankfulness to Him (Q2:43). Thus, those who are rich have been commanded to give Zakah as a way of appreciating the bounty of richness, which is not their making. Therefore, when the rich transfer a prescribed portion of their wealth to the poor, they are simply showing gratitude for this bounty and on the other hand, it is a form of compensation to the poor to assist them to live a reasonable life. Also, it is meant to enhance their socio-economic and religious welfare, which are germane to a meaningful and prosperous life. The amount generated from Zakah shall be distributed to the eight categories of Zakah expenditure shown in figure 1 (which has been introduced in this section to underscore the relevance of the theory under discussion). From figure 1, the Zakah mobilization region can be considered as the supply side (Revenue region) of the Zakah institution while the Zakah distribution region shall be regarded as the demand side (Expenditure region) because the beneficiaries are found in the region. Thus, the quantum amount of Zakah revenue generated from the rich (i.e. mobilization region) shall greatly determine the amount to be available for the distribution region, especially for poverty alleviation in Kano state. 
Mustafa, Baita, \& Adhama $\mid$ Quantitative Economic Evaluation of Zakah-Poverty Nexus in Kano State, Nigeria

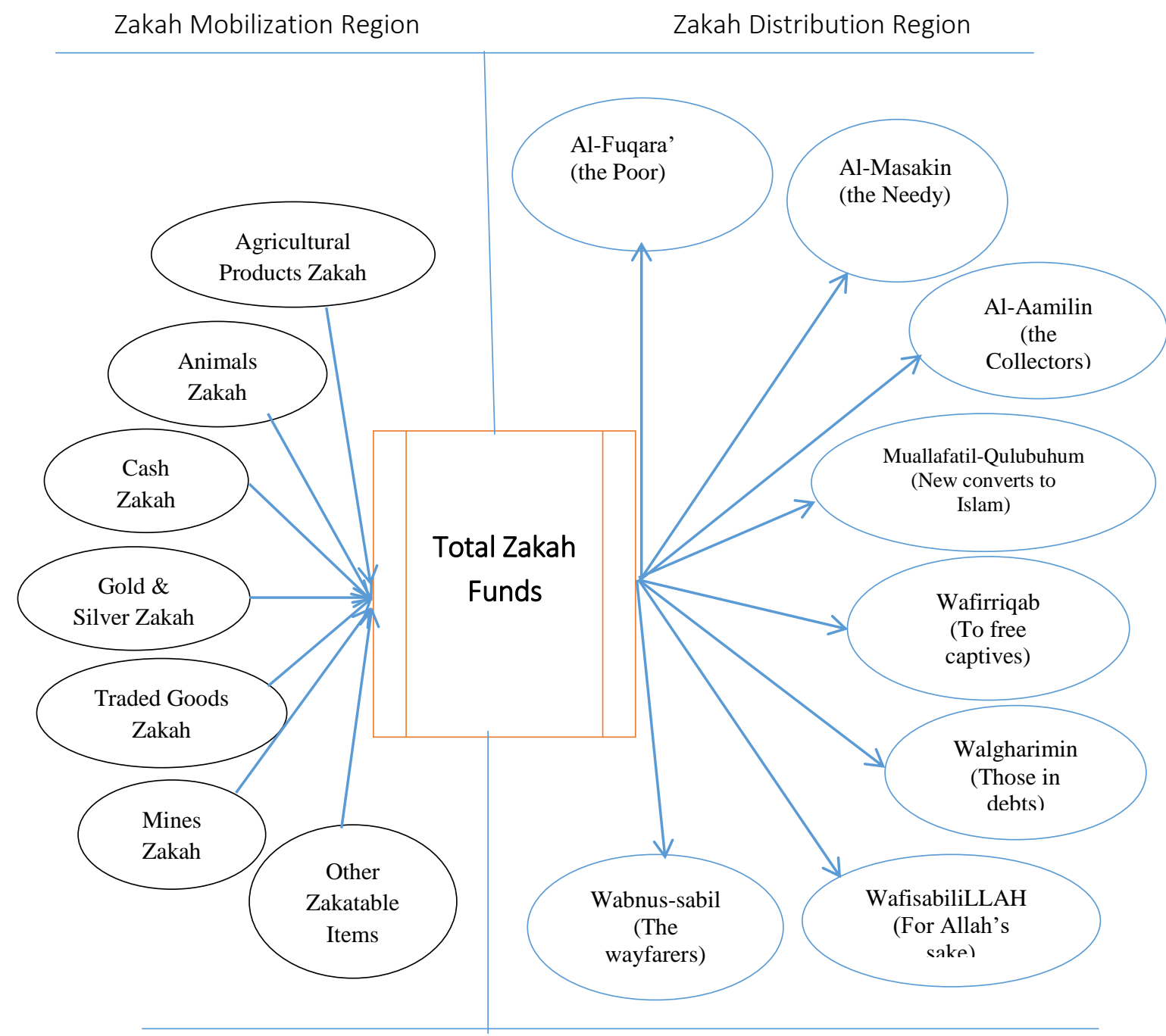

Figure 1. The Eight Heads of Zakah Expenditure and the various Zakatable Items Source: Adapted from Gusau (1992).

\section{Theory of Solidarity}

This theory was espoused by Al-Qardawi (2000) in his celebrated work on Figh az-Zakah. The theory serves as an important theoretical underpinning for vibrant and educative discourse on Zakah. The theory states that human beings are social creatures (i.e. homo sociologicus) and that in the process of becoming an important personality in life or acquiring ones' wealth, society and environment play a crucial role. As such, the people surrounding us should benefit from the wealth acquired. Furthermore, Ibn Khaldun cited in Dusuki (2011) submits that the principle of solidarity suggests a Group-based model (GBM), which makes individuals responsible for collective interests and makes them subservient to the general will and interest of the people. 
Mustafa, Baita, \& Adhama $\mid$ Quantitative Economic Evaluation of Zakah-Poverty Nexus in Kano State, Nigeria

Also, this principle is in harmony with Islamic brotherhood (Al-Ukhwah49:10) and the principle of cooperation ( $T a^{\prime}$ awun - Q5:2). Importantly, this theory establishes that society contributes to the wealth of the rich and thus, by way of appreciation, the society should be compensated through transfer of certain portions of the wealth for the benefit of the society and by extension the less endowed. This position is consistent with the principle of compensation in Welfare economics. Essentially, this is what Zakah system does in society with the prescribed $2.5 \%$ of the zakatable cash of the endowed ones in Muslim societies. Hence, the rich and the poor shall become mutual gainers of the institution of Zakah, in terms of welfare improvement and economic prosperity. Through this circular flow of wealth therefore, the society is saved from socio-economic and political crises like hatred, begging, prostitution, poverty, and unemployment, among others.

\subsection{Previous Studies}

Some of the empirical studies on Zakah institution and poverty alleviation include a study by Abdullahi (2006), which examines the impact of Zakah on beneficiaries in six (6) local government areas of Kano metropolis. Questionnaire and Key informant interview (KII) methods were adopted for data collection with the use of 577 as respondents and six (6) for KII. The findings from the study show that Zakah institution contributed to the enhancement of the well-being of the respondents but did not take them out of poverty. Other findings revealed that $17 \%$ of the respondents were dissatisfied with the management of Zakah in terms of distribution by the Kano State Zakah and Hubusi Commission. Another study by Ashafa (2014) investigates the distribution of Zakah in Lagos and Ogun states, Nigeria. The study examined the activities of NGOs working on Zakah collection and distribution. The methods of data collection adopted by the study were simple random sampling and interviews with seven (7) Muslim NGOs in Lagos and Ogun states. The findings show that $\mathrm{ZI}$ has a positive effect on the beneficiaries, who were empowered to become business owners and students got scholarships into various higher institutions. Nevertheless, the study revealed that $\mathrm{ZI}$ is confronted with challenges like inefficient management, lack of proper record-keeping by the Zakah agencies, circumvention by eligible payers and lack of trust, among others. A similar study by Abdussalam, Johari, and Alias (2015) examined the effectiveness of Zakah on poverty reduction in Kwara state, Nigeria with focus on the womenfolk. The study adopted a mixed method by utilizing 360 copies of questionnaire and an interview for data collection. The findings from the study were not consistent with the Zakah-effectiveness hypothesis because Zakah does not have a significant impact on poverty alleviation among most recipients. However, the study notes that ineffective Zakah management in

IJIEF: International Journal of Islamic Economics and Finance, 3(1), 21-50|26 
Mustafa, Baita, \& Adhama $\mid$ Quantitative Economic Evaluation of Zakah-Poverty Nexus in Kano State, Nigeria

the state was responsible because Zakah is being managed by an individual Muslim scholar and more so, the amounts distributed were also not significant enough to alleviate poverty among the poor and needy, especially the womenfolk. Thus, if $\mathrm{Zl}$ is to make any meaningful impact on the beneficiaries, the rules and regulations for its operations must be faithfully be followed.

Another study was conducted by Ahmad, Othman and Salleh (2015) on the Zakah distribution and the satisfaction level of Zakah recipients on Zakah management in Malaysia, having the majority of the respondents as poor and needy people. The study adopted the questionnaire method to generate data using six (6) Likert scale. The findings indicate that the recipients are positively impacted by the Zakah gesture. Nevertheless, the beneficiaries expressed dissatisfaction over the waiting period (i.e. three weeks) before they could receive Zakah. Although the beneficiaries expressed appreciation for receiving Zakah, they were disappointed with the management of Zakah in general by the Zakah agency. In another study by Ali and Saaid (2016), they investigated the impact of Zakah on poverty alleviation in Sudan with the use of a structured questionnaire of 50 copies to collect data. Their findings indicate that despite some operational inefficiencies and challenges confronting the Sudanese Zakah Chamber, Zakah positively and significantly impacts on poverty. Furthermore, a pilot study on the institution of Zakah for poverty alleviation in Kano state by Mustafa et al. (2017b) utilized 165 copies of the questionnaire in three (3) local government areas of Kano metropolis (i.e. Dala, Fagge and Kano Municipal) to gauge the opinions and perceptions of Zakah payers. The findings from this study revealed that the four-dimensional constructs satisfy the reliability and validity tests. Also, the study indicates that $98.65 \%$ of the respondents are businessmen and women with some of them paying as much $\mathrm{N100million}$ as Zakah in the last 15 to 20 years. In the same vein, $80 \%$ of Zakah payers are relatively young people of 25 to 55 years with some of them being old beneficiaries of Zakah. This finding is an indication of Zakah's impact and potentials in Kano state, which must be optimized.

In a more recent study on the role of Zakah distribution programs on poverty alleviation and income inequality reduction in West Java (Indonesia), which was conducted by Ayuniyyah, Pramanik, Md Saad and Ariffin (2018); they adopted the questionnaire method using 1,309 Zakah beneficiaries managed by the National Zakat Board of Indonesia (BAZNAS). The study revealed that Zakah distribution programs by BAZNAS are capable of significantly alleviating poverty and reducing income inequality. This is because the material and spiritual conditions of the observed households both in the urban and rural areas were improved one year after their enrolment into the

IJIEF: International Journal of Islamic Economics and Finance, 3(1), 21-50|27 
Mustafa, Baita, \& Adhama $\mid$ Quantitative Economic Evaluation of Zakah-Poverty Nexus in Kano State, Nigeria

Zakah distribution programs. Thus, the falah index adopted indicates an approximately $60 \%$ increase in the well-being of the beneficiaries. This finding, therefore, supports Zakah-effectiveness hypothesis in the literature.

\subsection{Conceptual Framework}

Flowing from the conceptual understanding of $\mathrm{Zl}$ and poverty alleviation in this study, the conceptual model of Zainal, Abu Bakar and Saad (2016) was adapted. In this direction, the conceptual model is hereby presented in figure 2, which is based on poverty alleviation as the dependent variable while Zakah payers' awareness and perceptions (ZAP), their Zakah payments (ZP) and Zakah management (ZM) serve as the independent/explanatory variables.

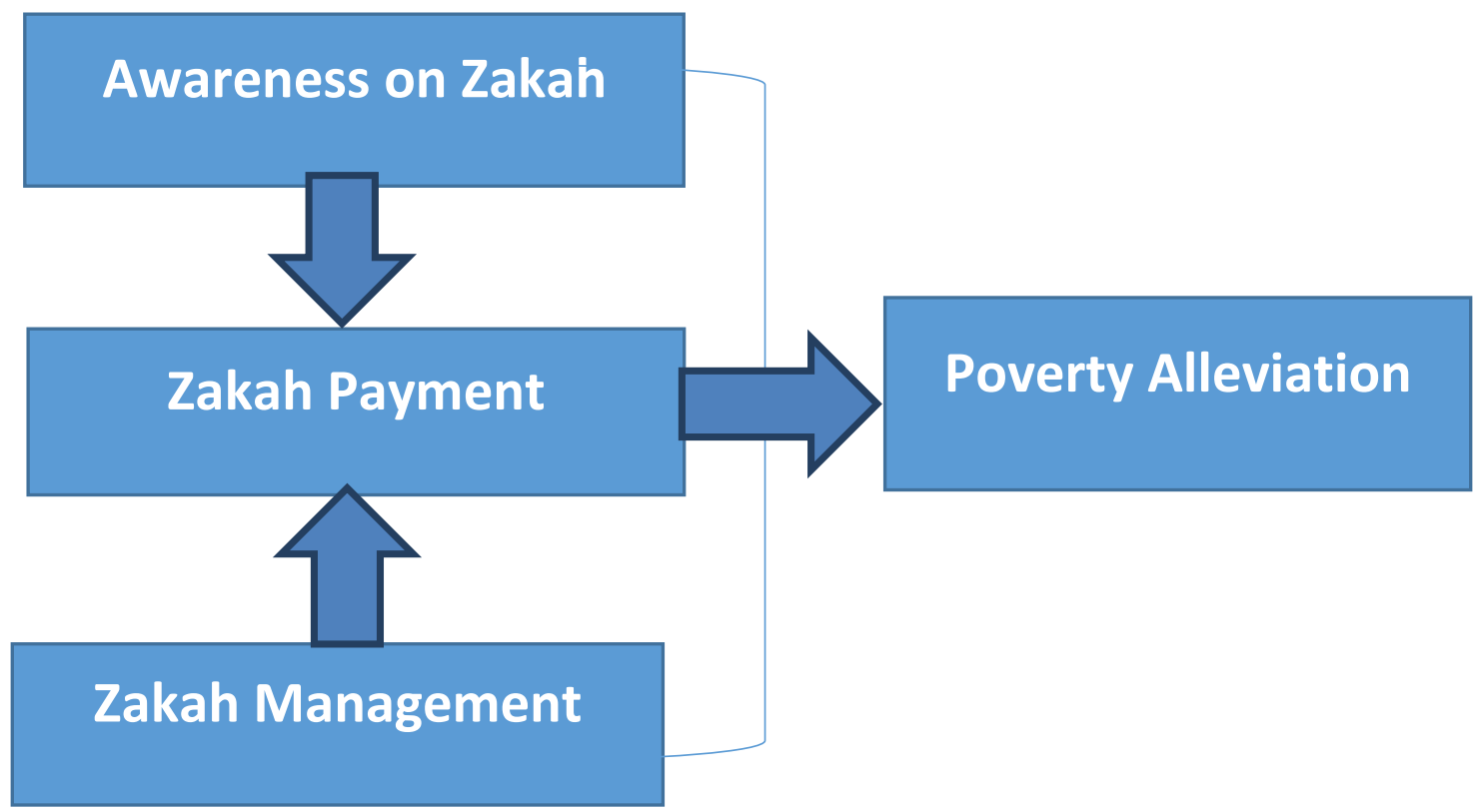

Figure 2. Conceptual Model of Zakah Institution for Poverty Alleviation in Kano State Source: Adapted from Zainal, Abu Bakar and Saad (2016).

The eight (8) metropolitan local government areas in the state were selected for investigation utilizing questionnaires and key informant interview (KII) methods for data collection. Essentially, this study makes some interesting contributions through a quantitative economic approach for a better understanding of the socio-economic and finance significance of $\mathrm{ZI}$ as a potent and viable Islamic social finance and security measure for poverty alleviation. 
Mustafa, Baita, \& Adhama $\mid$ Quantitative Economic Evaluation of Zakah-Poverty Nexus in Kano State, Nigeria

\section{Methodology}

Kano state is the most populated state in Nigeria with an estimate of over 15 million people and a Muslim majority of about $95 \%$. The state is one of the oldest states in the country with official creation in May 1967. Her Islamic heritage of civilization, commerce, and scholarship dates back to the period of Dawlatul Usmaniyyah (1804-1903) as an eminent Emirate as of 1860 (Muktar, 2017; Mustafa et al. 2017a). Kano state is a commercial nerve centre with the manufacturing and agricultural sectors as dominants. The state also commands over 3 million hectares of cultivable land, which are usable for the production of groundnuts/peanuts, rice, grains, and livestock among others. Kano state is made up of 44 local government areas (LGAs), which are divided into urban (Kano metropolis) with eight and rural 36 LGAs. The last National census of 2006 was 9,383,682 people (National Population Commission, 2006; Mustafa et al., 2017a). Considering the population density of the state, time constraint and paucity of financial resources, Kano metropolis of eight (8) LGAs (with 2,828,861 people), has been chosen as the study area (see Appendix I for the distribution of the population). Importantly, the justifications for the choice of Kano metropolis as the study area are rooted in the fact that they constitute a more educationally advanced and Islamically informed population with commercial and business orientations as well as accommodating high ability Zakah payers.

\subsection{Data}

Given the paucity of data and empirical works in this area, especially as it relates to Kano state, this study utilized primary data through questionnaire administration and key informant interview (KII) in Kano metropolis. The population adopted for this study consists of the entire households in Kano metropolis, who are all potential Zakah payers. According to the 2006 National Population Census for Kano metropolis, the population was 2,828,861 (see Appendix I for the distribution of the population). In this connection, the determination of the sample size for this study adopted the recommendation of Krejcie and Morgan (1970) that 384 copies of questionnaires for a population of $1,000,000$ people and above are appropriate. As such, since the population is almost 3million people, the recommendation of Krejcie and Morgan (1970) of 384 was multiplied by 3 and approximated to 1,230 copies of questionnaires to take care of sampling error. In this connection, the questionnaires of Abdullahi (2006) and Nadzri, AbdRahman and Omar (2012) were adapted and a structured questionnaire with a seven (7) point Likert scale was adopted to generate data from Zakah payers in Kano metropolis.

IJIEF: International Journal of Islamic Economics and Finance, 3(1), 21-50|29 
Mustafa, Baita, \& Adhama $\mid$ Quantitative Economic Evaluation of Zakah-Poverty Nexus in Kano State, Nigeria

Table 1. Distribution of Sample Size in Kano Metropolis

\begin{tabular}{llcc}
\hline S/N & Local Government Area & No. of Sample Size & \% Share \\
\hline 1. & Fagge & 250 & 20.3 \\
2. & Dala & 220 & 17.9 \\
3. & Kano Municipal Council (KMC) & 220 & 17.9 \\
4. & Ungogo & 100 & 8.1 \\
5. & Gwale & 120 & 9.8 \\
6. & Kumbotso & 100 & 8.1 \\
7. & Tarauni & 100 & 8.1 \\
8. & Nassarawa & 120 & 9.8 \\
\hline & Total & 1230 & 100 \\
\hline
\end{tabular}

Source: Authors' Computation (2018).

Therefore, table 1 provides the breakdown of the sample size distributed to the eight (8) LGAs. Also, secondary data was obtained from various published sources like the annual reports of the Kano State Zakah and Hubusi Commission (KSZHC) and various journal articles available on Zakah institution and poverty in Nigeria and beyond.

\subsection{Model Development}

This study seeks to empirically investigate the potential revenue base of the Zakah institution for poverty alleviation in Kano state. Also, the study accounts for the positive effect of Zakah institution on poverty alleviation and ascertain whether prudent management of Zakah institution is germane to achieving poverty alleviation in Kano state. In this direction, the three (3) hypotheses to be validated are:

H1: Zakah institution has an enormous revenue base for poverty alleviation in Kano state.

H2: Zakah institution has positive impacts on poverty alleviation in Kano state.

H3: Prudent management of Zakah institution is germane for poverty alleviation.

Flowing from the conceptual framework presented in figure 2, the economic specification of Zakah-poverty alleviation nexus is provided in line with the model specification of Mustafa, Baita and Mamman (2018) and Zainal et al. (2016):

$P O V=f(Z A P, Z P, Z M)$

Here:

POV = Poverty alleviation

ZAP = Zakah awareness

$Z P$ = Zakah payment

$Z M=$ Zakah management

IJIEF: International Journal of Islamic Economics and Finance, 3(1), 21-50|30 
Mustafa, Baita, \& Adhama $\mid$ Quantitative Economic Evaluation of Zakah-Poverty Nexus in Kano State, Nigeria

Against this background, the econometric specification of the model for estimation in this study is hereby given as a multiple regression model, which is in conformity with the conceptual model provided in figure 2 and the model specification of Mustafa, Baita and Mamman (2018) and Zainal et al. (2016). As such, the model is specified as follows:

$$
P O V_{i}=\beta_{0}+\beta_{1} Z A P_{i}+\beta_{2} Z P_{i}+\beta_{3} Z M_{i}+\varepsilon_{i} . \quad 2
$$

\subsection{Method}

The copies of the questionnaire administered comprised two (2) major parts. Part "A" contains demographic information of the respondents while Part "B" provides information on the four (4) dimensional constructs adopted in this study with 23 items. Also, key informant interview (KII) was utilized to gather useful information from some selected high ability Zakah payers from the business group and the academia. To capture the identified variables, which were considered germane to the econometric model, multiple regression model was adopted in line with earlier studies like Mustafa, Baita and Mamman (2018) and Zainal et al. (2016). As rightly noted by Wooldridge (2009), multiple regression analysis is more amenable to ceteris paribus analysis because it provides for explicit control of other factors that simultaneously affect the dependent variable. In this regard, he posits that "The multiple regression model is still the most widely used vehicle for empirical analysis in economics and other social sciences" (p. 68).

Furthermore, to achieve robust responses, multistage and convenience sampling methods were employed for the allocation and distribution of questionnaires. As rightly noted by Wedgewood and Sansom (2003), a multistage sampling technique is appropriate when big cities, wider geographical areas across cities or urban and rural settlements are involved in a study. In line with the rule of thumb for conducting a large scale study of this nature, the survey instrument was subjected to pilot study for its validity and reliability tests by administering 165 copies of the questionnaire in selected three LGAs (i.e. Dala, Fagge and KMC). In this regard, the validity test, which is made-up of face and content analysis was achieved. Similarly, the reliability test was successful by recording an overall reliability score of 0.81 for the four (4) dimensional constructs. Table 2 provides more information on the reliability test conducted.

IJIEF: International Journal of Islamic Economics and Finance, 3(1), 21-50|31 
Mustafa, Baita, \& Adhama $\mid$ Quantitative Economic Evaluation of Zakah-Poverty Nexus in Kano State, Nigeria

Table 2. Result of Pilot Study on Reliability Test for the Dimensional Constructs

\begin{tabular}{lcccc}
\hline $\begin{array}{l}\text { Dimensional } \\
\text { Constructs }\end{array}$ & \multicolumn{2}{c}{$\begin{array}{c}\text { Before removing the items } \\
\text { Cronbach's } \\
\text { alpha }\end{array}$} & $\begin{array}{c}\text { After removing the items } \\
\text { No. of Items }\end{array}$ & $\begin{array}{c}\text { Nonbh's } \\
\text { alpha }\end{array}$ \\
\hline Zakah awareness & 7 & 0.79 & 6 & 0.80 \\
Zakah payment & 9 & 0.73 & 7 & 0.82 \\
Zakah management & 6 & 0.74 & 5 & 0.77 \\
Poverty alleviation & 7 & 0.60 & 5 & 0.67 \\
\hline
\end{tabular}

Source: Mustafa et al. (2017b).

In this vein, the six items removed from the survey instrument, which makes it 23 items include: item 1 from Zakah awareness and perceptions (ZAP) construct, items 9 and 11 from Zakah payment (ZP) construct, item 22 from Zakah management (ZM) construct and items 27 and 29 from Poverty alleviation (POV) construct.

\section{Results and Analysis}

\section{1. $\quad$ Results}

\section{Outcomes of Administered Questionnaire}

This study utilized 1,230 copies of the questionnaire, which were administered in eight (8) LGAs of Kano metropolis with each local government allocated according to its peculiarities as noted in Appendix A. Nevertheless, 1,129 copies of questionnaire were returned but only 899, which represents $73 \%$ could be used for analysis. As such, table 3 presents the breakdown of the copies of the questionnaire distributed to the sampled local governments. The table indicates that Fagge LGA received the highest copies of the questionnaire (250) and also, returned the highest number of usable questionnaires (232), which represents $25.81 \%$; followed by Dala $=$ 220 with $21.13 \%$ usable and $\mathrm{KMC}=220$ with $17.69 \%$ usable.

IJIEF: International Journal of Islamic Economics and Finance, 3(1), 21-50|32 
Mustafa, Baita, \& Adhama $\mid$ Quantitative Economic Evaluation of Zakah-Poverty Nexus in Kano State, Nigeria

Table 3. Rate of Response on Administered Questionnaire

\begin{tabular}{lllll}
\hline Local & Allocated & Returned & Usable & \% Share \\
Government & Questionnaires & Questionnaires & Questionnaires & \\
\hline Fagge & 250 & 243 & 232 & 25.81 \\
Dala & 220 & 217 & 190 & 21.13 \\
KMC & 220 & 215 & 159 & 17.69 \\
Gwale & 120 & 100 & 87 & 9.68 \\
Nassarawa & 120 & 94 & 28 & 3.11 \\
Tarauni & 100 & 96 & 82 & 9.12 \\
Kumbotso & 100 & 75 & 55 & 6.12 \\
Ungogo & 100 & 89 & 66 & 7.34 \\
\hline Total & 1230 & 1129 & 899 & 100 \\
\hline
\end{tabular}

Source: Authors' Computation (2018).

Surprisingly, the least usable copies of the questionnaire were from Nassarawa (3.11\%); even though, the most populated among the LGAs in the state. This is so because of its peculiarities in terms of the existence of small markets in the LGA as compared to Fagge, Dala and KMC LGAs with big markets. Also important to be stated is that most usable copies of the questionnaire for this study emanated from three (3) LGAs of Fagge, Dala, and $\mathrm{KMC}$ because they accounted for 581 copies of the questionnaire (i.e. $64.6 \%)$.

\section{Profile of Respondents}

The demographic characteristics of the respondents are presented in table 4. Adopting crosstab analysis, the results from the table indicates that $92.89 \%$ are males while only $7.11 \%$ are females. In terms of educational status, most of them are secondary school certificate holders $=311$, which represents $35.18 \%$, very few are Ph.D. holders (0.90\%) and $10.86 \%$ represents the other educational levels not indicated in the options. 
Mustafa, Baita, \& Adhama $\mid$ Quantitative Economic Evaluation of Zakah-Poverty Nexus in Kano State, Nigeria

Table 4: Demographic Characteristics of the Respondents

\begin{tabular}{|c|c|c|}
\hline Demographic Status & Frequency & Percentage \\
\hline \multicolumn{3}{|l|}{ Education Level } \\
\hline Primary & 145 & 16.40 \\
\hline Secondary & 311 & 35.18 \\
\hline Degree & 145 & 16.4 \\
\hline Masters & 38 & 4.30 \\
\hline Ph.D. & 08 & 0.90 \\
\hline Non-formal & 141 & 15.95 \\
\hline Others & 96 & 10.86 \\
\hline Total & 884 & 100 \\
\hline \multicolumn{3}{|l|}{ Occupation } \\
\hline Business & 710 & 84.42 \\
\hline Civil service & 94 & 11.18 \\
\hline Others & 37 & 4.40 \\
\hline Total & 841 & 100 \\
\hline \multicolumn{3}{|l|}{ Age } \\
\hline $21-30$ & 88 & 9.88 \\
\hline $31-40$ & 309 & 34.68 \\
\hline $41-50$ & 264 & 29.63 \\
\hline $51-60$ & 176 & 19.75 \\
\hline 60 and above & 53 & 5.95 \\
\hline Total & 890 & 100 \\
\hline \multicolumn{3}{|l|}{ Gender } \\
\hline$\overline{\text { Female }}$ & 62 & 7.11 \\
\hline Male & 810 & 92.89 \\
\hline Total & 872 & 100 \\
\hline \multicolumn{3}{|c|}{ Major Beneficiaries of Zakah } \\
\hline Poor \& Needy & 370 & 41.86 \\
\hline Orphanage & 42 & 4.75 \\
\hline Family \& Friends & 162 & 18.33 \\
\hline Zakah Commission & 14 & 1.58 \\
\hline Others & 13 & 1.47 \\
\hline More than one category & 283 & 32.01 \\
\hline Total & 884 & 100 \\
\hline \multicolumn{3}{|c|}{ Once a Beneficiary of Zakah } \\
\hline No & 551 & 62.76 \\
\hline Yes & 327 & 37.24 \\
\hline Total & 878 & 100 \\
\hline
\end{tabular}

Source: Computed by the Authors (2018).

Also, most of the respondents are businessmen and women in terms of occupation $=710(84.42 \%)$, civil servants are just $11.18 \%(94)$ and other types of occupation represent $4.40 \%$ (37). In general, $34.68 \%$ (309) of the respondents fall within the age group of 31-40 years, which represents the highest respondents and $29.63 \%$ (176) captures those within the age bracket of 41-50 years. Furthermore, majority of the Zakah beneficiaries are the poor and needy, which represents $41.86 \%$, other beneficiaries include orphanage (4.75\%), Zakah Commission barely attracted $1.58 \%$ (14) of the respondents for Zakah payment; this means a lot for the Commission in terms of efficiency and public trust.

IJIEF: International Journal of Islamic Economics and Finance, 3(1), 21-50|34 
Mustafa, Baita, \& Adhama $\mid$ Quantitative Economic Evaluation of Zakah-Poverty Nexus in Kano State, Nigeria

Descriptive Statistics and Preliminary Tests

(i.) Summary of Descriptive Statistics

Table 5: Summary Statistics of the Variables

\begin{tabular}{lcccc}
\hline $\begin{array}{l}\text { Statistics } \\
\text { Criteria }\end{array}$ & $\begin{array}{l}\text { Zakah } \\
\text { Awareness }\end{array}$ & $\begin{array}{l}\text { Zakah } \\
\text { Payment }\end{array}$ & $\begin{array}{l}\text { Zakah } \\
\text { Management }\end{array}$ & $\begin{array}{c}\text { Poverty } \\
\text { Alleviation }\end{array}$ \\
\hline Observations & 899 & 899 & 899 & 899 \\
Mean & 5.9100 & 6.4587 & 5.8846 & 6.0392 \\
Median & 6.0000 & 6.5714 & 6.0000 & 6.0000 \\
Standard & & & & .75516 \\
Deviation & .88763 & .54101 & .86682 & -1.018 \\
Skewness & -1.538 & -2.856 & -1.115 & 2.225 \\
Kurtosis & 3.373 & 2.146 & 2.195 & 1.60 \\
Minimum & 1.00 & 1.00 & 1.20 & 7.00 \\
Maximum & 7.00 & 7.00 & 7.00 & \\
\hline
\end{tabular}

Source: Computed by the Authors (2018).

The summary statistics of dependent and independent variables are presented in table 5. The total observations used for analysis are 899 and the mean scores for all four (4) variables fall within 5.885 and 6.459. The variable of Zakah payment recorded the highest mean score of 6.459 with a minimum of 1 and a standard deviation of .541. This depicts the highest perceptions of Zakah institution and poverty alleviation with the least variability of perceptions among the respondents. The mean score for Zakah management is the least with 5.885, a minimum of 1.20 and the highest standard deviation of .867 .

This implies that Zakah management has the least perception among the respondents, which also accounts for the low patronage of the Zakah Commission because only 14 respondents gave their Zakah to the Commission (see Table 4). This scenario could be explained by a lack of public trust and confidence in the management of the Zakah Commission. In this direction, the data obtained for this study could be considered as symmetric and normally distributed as evident in table 5 .

\section{(ii.) Reliability Test}

The score of the overall reliability test has Cronbach's alpha score of 0.8, which is greater than the benchmark of 0.6 adopted for this study (see Sekaran, 2003). Thus, with this high level of reliability score, it can safely be concluded that internal consistency exists among the four major dimensional constructs adopted for this study. Furthermore, the result in table 6 shows the reliability scores for the individual dimensional constructs with Zakah payment having the highest score of 0.8 followed by Zakah awareness and Zakah management having 0.7 each and Poverty alleviation has the least 
Mustafa, Baita, \& Adhama $\mid$ Quantitative Economic Evaluation of Zakah-Poverty Nexus in Kano State, Nigeria

Table 6. Result of Reliability Test

\begin{tabular}{lcc}
\hline Variables & $\begin{array}{c}\text { Cronbach's } \\
\text { Alpha Score }\end{array}$ & No. of Items \\
\hline Zakah Awareness & 0.7 & 6 \\
Zakah Payment & 0.8 & 7 \\
Zakah Management & 0.7 & 5 \\
Poverty Alleviation & 0.6 & 5 \\
\hline \multicolumn{2}{c}{ Source: Computed by the Authors (2018). }
\end{tabular}

score of 0.6. The four constructs are reliable for this study and as such, whatever results emanating from this study should, therefore, be considered reliable and acceptable because the reliability test satisfied the rule of thumb.

(iii.) Correlation Matrix

The correlation matrix has been adopted to show the direction of the relationship between dependent and explanatory variables and even among the explanatory variables. Therefore, the sign of the coefficient ranges from 1 to 1 and this implies that a negative coefficient connotes an indirect relationship while a positive coefficient means a direct relationship. Hence, the closer the value of the coefficient is to 1 or -1 , the stronger the correlation. In this direction, table 7 shows that all the coefficients are positive implying direct correlation among all the variables. More importantly, the coefficient of Zakah management concerning poverty alleviation has the highest value of 0.54 , which is the closest to 1 . It can be deduced that Zakah management strongly and positively correlates with poverty alleviation, which suggests that better management of $\mathrm{Zl}$ shall positively influence poverty alleviation in Kano state. Also, the coefficient of Zakah payment as it relates to Zakah management is 0.42 , which represents the second highest value in the table.

In the same vein, Zakah payment positively correlates with Zakah management, which implies that the patronage level of Zakah management agency like KSZHC is determined by the level of perceptions and trust the Zakah payers have in the management of Zakah. Thus, it implies that the prudent management of Zakah shall lead to higher payment of Zakah to the Zakah Commission. This further suggests that adequate and proper management of $\mathrm{Zl}$ shall go along in increasing the patronage level and trust in Zakah Commission by Zakah payers. Furthermore, Zakah payment also positively correlates with poverty alleviation at an impressive value of 0.41 . It connotes that more payment of Zakah shall have positive impacts on poverty alleviation.

IJIEF: International Journal of Islamic Economics and Finance, 3(1), 21-50|36 
Mustafa, Baita, \& Adhama $\mid$ Quantitative Economic Evaluation of Zakah-Poverty Nexus in Kano State, Nigeria

Table 7. Result of Correlation Analysis

\begin{tabular}{lcccc}
\hline Variables & $\begin{array}{c}\text { Zakah } \\
\text { awareness }\end{array}$ & $\begin{array}{c}\text { Zakah } \\
\text { payment }\end{array}$ & $\begin{array}{c}\text { Zakah } \\
\text { management }\end{array}$ & $\begin{array}{c}\text { Poverty } \\
\text { alleviation }\end{array}$ \\
\hline Zakah awareness & 1 & & & \\
Zakah payment & 0.283 & 1 & & \\
Zakah management & 0.317 & 0.421 & 1 & \\
Poverty alleviation & 0.236 & 0.412 & 0.543 & 1 \\
\hline
\end{tabular}

Source: Computed by the Authors (2018).

High Ability Zakah Payers and New Zakah Payers

(i.) High Ability Zakah Payers

From the data collected, it shows that 707 Zakah payers fall into the category of high ability Zakah payers from $\$ 75,000$ - $1 \mathrm{~m}$ and above, which represents $78.6 \%$. This is certainly an indication of a high level of potential revenue base of Zakah institution in the state. Breaking the total figure of 707 , it means that those who make average payment of $1 \mathrm{~m}$ and above per annum are 93 Zakah payers while those who paid $\$ 75,000-\$ 999,999$ are 614 , which represents $68.3 \%$. Also, Zakah payers from $\$ 25,000$ to less than \#1m are 795, which says a lot about Zakah revenue potentials. Interestingly, Fagge LGA produced the highest number of high ability Zakah payers with 225 respondents, which represents $31.8 \%$. This finding is expected because Fagge hosts the biggest markets in the state. Other LGAs with similar record like Fagge include Dala (161), KMC (106), and Gwale (61) among others. Thus, it is obvious that high revenue potential of Zakah exists in the metropolis.

(ii.) New Zakah Payers

One of the outcomes this study is expected to verify is the possibility of whether old beneficiaries of Zakah in Kano state are paying Zakah, which is capital "YES" from the result. A total of 327 new Zakah payers have been identified, which represents $36.7 \%$ of the 899 respondents and 84 of them fall in the category of high ability Zakah payers of 1 million and above with Dala LGA recording the highest number of Zakah payers (56) in this category. The economic implication of this finding is that the poor and needy who were once beneficiaries of Zakah some few years ago are now Zakah payers i.e. they have shifted from being at the deficit unit to surplus unit, and thereby qualified to pay Zakah. This finding is certainly very interesting for poverty alleviation through Zakah.

Regression Analysis and Diagnostics Test

(i.) Regression Results

The result of the regression model presented in table 8 indicates that all the explanatory variables have a positive effect on poverty alleviation with Zakah

IJIEF: International Journal of Islamic Economics and Finance, 3(1), 21-50|37 
Mustafa, Baita, \& Adhama $\mid$ Quantitative Economic Evaluation of Zakah-Poverty Nexus in Kano State, Nigeria

Table 8. Result of Regression Estimates

\begin{tabular}{|c|c|c|c|c|c|}
\hline Variables & Coefficients & $\begin{array}{l}\text { Standard } \\
\text { error }\end{array}$ & t-stat & P-value & \\
\hline Constant & 1.420 & 0.286 & 4.965 & 0.000 & \\
\hline $\begin{array}{l}\text { Zakah } \\
\text { awareness }\end{array}$ & 0.035 & 0.027 & 1.313 & 0.189 & \\
\hline Zakah payment & 0.331 & 0.048 & 6.936 & 0.000 & \\
\hline $\begin{array}{l}\text { Zakah } \\
\text { management }\end{array}$ & 0.386 & 0.029 & 13.485 & 0.000 & \\
\hline R-Square & $\begin{array}{l}\text { Adjusted R- } \\
\text { Square }\end{array}$ & $\begin{array}{l}\text { Std. Error of } \\
\text { the Estimate }\end{array}$ & $\begin{array}{c}\text { F- } \\
\text { statistics }\end{array}$ & $\begin{array}{l}\text { Prob (F- } \\
\text { statistics) }\end{array}$ & $\begin{array}{l}\text { Durbin - } \\
\text { Watson }\end{array}$ \\
\hline 0.341 & 0.339 & 0.618 & 141.211 & 0.000 & 1.507 \\
\hline
\end{tabular}

Source: Computed by the Authors (2018).

payment and Zakah management exhibiting a high level of significance level of $1 \%$ but Zakah awareness demonstrates no significance level. In this regard, Zakah payment recorded 0.331 coefficient, which connotes that a one-unit increase in Zakah payment will translate to 0.331-unit increase in poverty alleviation. In the same vein, Zakah management recorded the coefficient of 0.386, which suggests that a one-unit increase in the level and style of Zakah management in Kano state will lead to 0.386-unit increment in poverty alleviation.

\section{(ii.) Diagnostics Tests}

The diagnostics tests carried out include multi-collinearity, heteroskedasticity, normality, and autocorrelation. Thus, the results for both multicollinearity and heteroskedasticity are presented in table 9. In this direction, the variance inflation factor (VIF) or the tolerance criteria are often used to determine multi-collinearity and since acceptance condition of less than 5 for VIF or less than 1 for tolerance has been satisfied; it could be concluded that the assumption of no multi-collinearity is not violated. Also, the presence of heteroskedasticity is established since the significance levels of the t-statistics are less than 0.05 . Therefore, to fix the problem of heteroskedasticity, which is common in cross-sectional analysis and which was unavoidably recorded, robust regression analysis was employed to obtain robust standard errors (see Appendix II). Furthermore, the result for the normality of the residual error term is based on Shapiro-Wilk statistics of 0.958 at the significance level of 0.000 . Hence, it could be inferred that the residual error term is not normally distributed. Also, autocorrelation based on the Durbin-Watson criterion of 1.507, implies the rejection of the null hypothesis of no positive autocorrelation.

IJIEF: International Journal of Islamic Economics and Finance, 3(1), 21-50|38 
Mustafa, Baita, \& Adhama $\mid$ Quantitative Economic Evaluation of Zakah-Poverty Nexus in Kano State, Nigeria

Table 9. Result of Diagnostics Test

\begin{tabular}{lccc}
\hline Variables & Tolerance & VIF & Heteroskedasticity \\
\hline Zakat awareness & 0.883 & 1.133 & $-3.098(0.002)$ \\
Zakat payment & 0.790 & 1.265 & $2.939(0.003)$ \\
Zakat management & 0.768 & 1.302 & $-6.328(0.000)$ \\
\hline
\end{tabular}

Source: Computed by the Authors (2018).

Note: The significance levels are in parentheses.

\section{Outcomes of Interview with High Profile Zakah Payers}

Key informant interview (KII) method was adopted to gauge information from strategic stakeholders of $\mathrm{Zl}$ in Kano metropolis, especially from academia and the business class. In this regard, after a lot of attempts and follow-up due to their tight schedules, only seven (7) of the high profile Zakah payers (i.e. three among the academia and four from the business class) could be engaged for interview. Importantly, three Professors were interviewed. The two male Professors have other occupational engagements apart from lecturing like estate management, consultancy, and authoring of books, among others. As a matter of fact, among the most interesting discoveries of this interview are: (i.) that a leading businessman in Kano state distributed as much as over 200million as Zakah for the year 2017 to various categories of beneficiaries; (ii.) that academics despite their meagre resources and salary payments still have religious desire and commitment to paying Zakah to the poor and needy around them; and (iii.) the case of a leading woman transporter in the Northern part of Nigeria who started her business life with traditional grinding, laundry, crushing and cutting of woodlog at the age of 12 years and now 51 years old, makes a special appeal. Interestingly, she has two (2) driving schools and 130 employees directly working under her. She has economically empowered over 9,000 people in various capacities. To this end, other key issues discussed with the high profile Zakah payers are hereby thematically presented.

(i.) Impact of Zakah on the Beneficiaries

It is important to recall that the fundamental objective of Zakah is to alleviate poverty and economically empowered the poor and needy in Muslim societies (see Figure 1 for the stipulated Zakah beneficiaries as contained in Q9:60). According to the high profile Zakah payers, they all agreed that Zakah payment has made both short-run and long-run significant and positive impacts in the lives of the beneficiaries more than government empowerment projects. This is because some of the beneficiaries are now economically stable and self-contented. For instance, Zakah serves as an initial capital with which some of them are now proud

IJIEF: International Journal of Islamic Economics and Finance, 3(1), 21-50|39 
Mustafa, Baita, \& Adhama $\mid$ Quantitative Economic Evaluation of Zakah-Poverty Nexus in Kano State, Nigeria

owners of their businesses, houses and even paying Zakah to others as a result of the Zakah given to them some years ago. In this vein, it could safely be concluded that $\mathrm{ZI}$ is a capital enhancement mechanism, which can be used to promote and stimulate the Muslim economy. This submission also validates $\mathrm{H} 2$ on the positive link between $\mathrm{ZI}$ and poverty alleviation.

(ii.) Reservations on Zakah Management and the Ways Out

The interviewees noted that the government agency vested with the management of Zakah lacks the trust and confidence of the Zakah payers and the beneficiaries due to some problems such as inadequate publicity, lack of proper record-keeping, lack of proper management of Zakah revenue, insincerity and time-wasting by the workers and a host of others. To overcome the problems, the following suggestions were proffered: (i.) trusted and sincere people should be brought into the Commission because it is not an ordinary agency of government that every Tom, Dick and Harry like politicians should be involved in its management; (ii.) creating more public awareness on the significance of Zakah and the role of the Commission; (iii.) more education and training for the workers, the payers and the beneficiaries on how to productively utilize the Zakah fund; (iv.) insufficient amount being disbursed to beneficiaries; and ( $v$.) adequate supports from Kano state government to the Commission for enhanced operations and quality service delivery to all and sundry, especially to the Zakah payers and beneficiaries.

(iii.) Means and Methods for Enhancing Zakah Management in Kano State Given the educational background, experiences and exposure of the high profile Zakah payers, they were able to provide real and practical means by which Zakah institution could be revamped in Kano state; since Zakah institution is very strategic and fundamental to the faith and lives of Muslims. Hence, they identified the following models through which $\mathrm{ZI}$ can efficiently and effectively be managed in Kano state and Nigeria at large. The models include: (i.) management by individual Zakah payer as the case with all our interviewees; (ii.) committee of trusted and sincere personalities or Muslim NGO to collect and distribute Zakah; and (iii.) Government agency as the case with Kano, Sokoto and Zamfara states among others in Nigeria with qualified and trusted workers to manage Zakahfunds. However, this study holds that the three models could be adopted for a society like Kano state. This is to allow for more participation in Zakah management, which is a necessary condition for now.

IJIEF: International Journal of Islamic Economics and Finance, 3(1), 21-50| 40 
Mustafa, Baita, \& Adhama $\mid$ Quantitative Economic Evaluation of Zakah-Poverty Nexus in Kano State, Nigeria

\subsection{Analysis}

\section{Discussion of Empirical Findings}

From table 4, it can be inferred that a young and vibrant generation of Zakah payers between the age group of 31-50 years, which represents $64.31 \%$ exists in the state. This result implies that Zakah payment is sustainable considering the ages of this category of Zakah payers "if and only if" the State government promotes good governance, positive fiscal incentives and persistent public advocacy and awareness on the significance of $\mathrm{ZI}$ in Islam and Muslim society. Among the most interesting results emanating from table 4 is that 327 respondents (37.24\%), which is a very significant number, who are old Zakah beneficiaries are now Zakah payers. This means that they have been alleviated from poverty and thus, financially and economically buoyant enough to now pay Zakah. This result consistent with the result presented in table 8 and thus, validates $\mathrm{H} 1$ : that Zakah impacts positively on poverty alleviation in Kano state. This finding also underscores the revenue potentials of $\mathrm{ZI}$ in the state. Generally from table 4 , it can be deduced that the respondents represent a quality human capital development (HCD) in terms of their educational qualifications because the majority of them are secondary school certificate holders, degrees, masters and PhD holders, which collectively accounts for $56.7 \%$. By the results of the demographic characteristics, it could be deduced that the potential revenue base of Zakah exists. However, it needs to be revamped by the State government through good governance, especially through the Zakah Commission. Also, more public enlightenment and advocacy must be embarked upon by the Commission and other stakeholders like the Emirate and scholars, to optimally explore the available revenue potentials of $\mathrm{ZI}$ in the state.

Moreover, the findings from the regression results presented in table 8 indicate that all the explanatory variables have a positive effect on poverty alleviation with Zakah payment and Zakah management exhibiting a high level of significance level of $1 \%$ but Zakah awareness demonstrates no significance level. In this regard, Zakah payment recorded 0.331 coefficient, which connotes that a one-unit increase in Zakah payment will translate to 0.331 -unit increase in poverty alleviation. This finding validates $\mathrm{H} 2$ of this study, which supports earlier findings by Ashafa (2014), Ahmad et al. (2015), Abdussalam et al. (2015), Ali and Saaid (2016), Kefeli et al. (2017) and Ayuniyyah et al. (2018) on the positive effect of Zakah on poverty alleviation in Nigeria and Malaysia respectively. In the same vein, Zakah management recorded the coefficient of 0.386 , which suggests that a one-unit increase in the level and style of Zakah management in Kano state will lead to 0.386-unit

IJIEF: International Journal of Islamic Economics and Finance, 3(1), 21-50|41 
Mustafa, Baita, \& Adhama $\mid$ Quantitative Economic Evaluation of Zakah-Poverty Nexus in Kano State, Nigeria

increment in poverty alleviation. It is instructive to mention that Zakah management, which recorded the highest coefficient equally demonstrates the highest level of correlation. Hence, it can be concluded that Zakah management is the strongest determinant of poverty alleviation. This finding validates H3, which is consistent with the findings of Ibrahim (2015) and Mustafa et al. (2017a). Therefore, to achieve prudent management of Zakah, which is germane for poverty alleviation, men of sincerity and religious understanding and commitment are needed to run the affairs of the Zakah Commission with Islamic and conventional backgrounds in Islamic sciences and Accounting/Business Management/ Economics/Finance.

It is worthy to state that the explanatory variables demonstrate joint significance in explaining the dependent variable because the probability value of f-statistics is 0.000 . Similarly, the goodness of fit reveals that the adjusted $R^{2}$ is $34 \%$, which is appropriate and considered moderate for primary data. Also, the Durbin-Watson statistic of 1.507 is within the acceptable range and this implies that there is positive autocorrelation. The results presented on the fitness of the model established that the model used for this study is appropriate and reliable. Nevertheless, it needs to be stated that the $66 \%$ unaccounted for in the adjusted $R^{2}$ could largely be due to other variables not included since this study focus on Zakah payers and Zakah management only. Other variables that future studies need to investigate to account for the $66 \%$ are Zakah beneficiaries, Zakah rules, and regulations and a host of others. Nevertheless, the $\mathrm{R}^{2}$ score attained is consistent with the rule of thumb as noted by Falk and Miller (1992) and Chin (1998).

\section{Analysis of Qualitative Findings}

Essentially, the interview with the seven (7) personalities through the use of KII method proved to be very thoughts provoking and educative. In general, those interviewed fall within the age group of 47-65 years and they have been paying Zakah in the last 10-30years. On average, the high profile Zakah payers have paid between $3 \mathrm{~m}$ to 33 .5billion as Zakah to various beneficiaries like the poor and needy, women, orphans, relatives and friends. This gesture of the high profile Zakah payers has impacted positively on the well-being of the beneficiaries. By this submission, it implies that Zakah has positive impacts on the lives of the beneficiaries, which confirm $\mathrm{H} 1$. However, it is perturbing to state that only one of the high profile Zakah payers has ever patronized the Zakah Commission. This is connected to the lack of trust and confidence in the management of $\mathrm{Zl}$ as espoused by many of the interviewees. Some also complained of lack of awareness and

IJIEF: International Journal of Islamic Economics and Finance, 3(1), 21-50| 42 
Mustafa, Baita, \& Adhama $\mid$ Quantitative Economic Evaluation of Zakah-Poverty Nexus in Kano State, Nigeria

publicity of its activities. At this juncture, it is important to state that the KII method adopted has brought to limelight the genuine concerns of the rich people on the inadequate management of Zakah system. Nonetheless, some of the rich gave as much as $\$ 5 \mathrm{~m}$ to individual beneficiary to set-up personal business, which took such individual out of poverty. This is what Al-Qardawi (2000) refers to as permanent rehabilitation of Zakah beneficiaries, which will make them also become Zakah payers in the future. This supports the empirical findings of this study (see section 4.1.4).

\section{Contributions of this Study to the Economics of Zakah Discourse}

It is not a gainsaying that the results and findings attained in this study are certainly very interesting and a major contribution ahead of the study of Abullahi (2006), which also studied the same Kano metropolis, especially on the methodology adopted. This is in view of the large sample size adopted (i.e. 1,230 copies of the questionnaire as compared to his 577 copies), and certainly provides for less sampling error by the rule of the thumb. Also, the robustness and multiple techniques of analysis adopted (like descriptive statistics, Correlation matrix, regression estimate, diagnostics test, and crosstab analysis) gave this study a major edge above previous studies like Abdullahi (2006), Wali (2013), Ashafa (2014), Abdussalam et al. (2015) and Mustafa et al. (2017b) on Nigeria, Ali and Saaid (2016) on Sudan, Ahmad et al. (2015) and Kefeli et al. (2017) on Malaysia and Ayuniyyah, Pramanik, Md Saad and Ariffin (2018) on Indonesia.

In the same vein, this study also contributes in terms of the conceptual model (see Figure 2), which is the first of its kind in Zakah discourse, especially in Nigeria. Even though this study adapted the conceptual framework of Zainal et al. (2016), it has introduced new variables like Zakah awareness and perception, Zakah payment and Zakah management, in contradistinction to what Zainal et al. (2016) used in their framework. Thus, the conceptual model adapted in this study is, therefore, a new contribution to the body of knowledge, which future studies can adopt in better understanding the phenomena of Zakah institution and poverty alleviation nexus in their climes. Furthermore, this study has also contributed to the empirical literature on Zakah institution, particularly as it relates to the Nigerian society and economy. Most of the studies on Zakah institutions in Nigeria are largely historical, conceptual and theoretical (see Appendix III). This study has enriched the empirical literature on Zakah institution and poverty discourse in Muslim academic discourse by bringing in the Nigerian peculiarity and dimension of the subject matter. All in all, this study has made three important contributions: (i.) conceptual contribution by way of 
Mustafa, Baita, \& Adhama $\mid$ Quantitative Economic Evaluation of Zakah-Poverty Nexus in Kano State, Nigeria

introducing a new conceptual model on Zakah-poverty nexus; (ii.) methodological - in terms of adopting multiple techniques of data analysis, in order to attain robustness of results; and (iii.) empirical literature addition, have been achieved in this study.

\section{Conclusion and Recommendation}

\subsection{Conclusion}

This study empirically investigates the revenue base of Zakah institution and its impact on poverty alleviation in Kano state, Nigeria. In this direction, both questionnaires and key informant interview (KII) methods were adopted for the collection of data. For robustness to be achieved, five (5) techniques of analysis were adopted. Therefore, from the foregoing discussions and analyses of facts and figures, it is clear from the major findings that the potentials of $\mathrm{ZI}$ as a potent and sustainable source of public revenue for poverty alleviation is enormous. This is because of the significant Zakah payment from high ability Zakah payers and old beneficiaries. This finding also supports the forecasting hypothesis of Mustafa et al. (2017a) that Zl in Kano state has the revenue potentials of generating over 25 billion per annum. Furthermore, the positive link between $\mathrm{ZI}$ and poverty alleviation is also established. Again, the finding that prudent management of $\mathrm{Zl}$ is germane for poverty alleviation is indeed very instructive. This is because the Zakah management variable recorded a strong statistical significance level of $1 \%$ with the highest coefficient of 0.386 . Essentially, the findings from this study lend credence to the Zakah-effectiveness hypothesis. To this end, the submission of Mustafa and Maiyaki (2016) supports the central thesis of this study that, "The Kano State case study has revealed that the institution of Zakah portends a lot of potentials if given governmental supports and backing" (p. 11).

\subsection{Recommendation}

Flowing from the findings in this study, it is hereby recommended that $\mathrm{Zl}$ in Kano state needs to be greatly promoted among high ability Zakah payers through increased public advocacy and awareness as well as fiscal incentives and motivations. Moreover, Kano state government as a major stakeholder in Zakah management through the Zakah Commission should take the lead through exemplifying good governance in the form of more accountability and transparency in the management of Zakah revenue. More importantly, considering the revenue potentials of $\mathrm{Zl}$, which cannot be managed by just a Commission, a Ministry of Zakah and Hubusi Affairs is hereby proposed for establishment in the long-run, which should completely take charge of 
Mustafa, Baita, \& Adhama $\mid$ Quantitative Economic Evaluation of Zakah-Poverty Nexus in Kano State, Nigeria

poverty alleviation, economic empowerment, and other related matters. The proposed ministry should be headed by a seasoned scholar of integrity with Islamic and conventional backgrounds possibly in Islamic Social and Management Sciences. Similarly, a Council of Stakeholders should be put in place within the ministry to assist in mobilizing supports and public trust for the ministry. The council should have representatives from the Emirate Council, Council of Ulamas, Academia, Business class, Islamic organizations, Women organizations, and the Media. Furthermore, this study has only addressed the fundamental issue of Zakah payers and partly, Zakah management. Therefore, future studies should focus on other issues like Zakah beneficiaries and the impact of Zakah on their well-being, impact of Zakah management on the beneficiaries, Zakah system and corporate organizations and a host of others.

\subsection{Acknowledgments}

The Research Team profoundly acknowledges the Islamic Research and Training Institute (IRTI), Islamic Development Bank (IDB) Group, for the sponsorship. There is no doubt, the wealth of experiences gathered shall forever be useful in our future academic undertakings. Similarly, we appreciate Tertiary Education Trust Fund - TETFund (Nigeria), for the international conference sponsorship in Sunway University, Malaysia (2019).

IJIEF: International Journal of Islamic Economics and Finance, 3(1), 21-50| 45 
Mustafa, Baita, \& Adhama $\mid$ Quantitative Economic Evaluation of Zakah-Poverty Nexus in Kano State, Nigeria

\section{References}

Abdullahi, S. A. (2006). An assessment of the impacts of zakah on the beneficiaries in the six local government areas of Kano metropolis (Sponsored Research Project). Kano: Kano State Zakkah and Hubusi Commission.

Abdussalam, O. I., Johari, F. \& Alias, M. (2015). Is zakah effective to alleviate poverty in a Muslim society?: A case of Kwara state, Nigeria. GJAT, 5(1), 33-41.

Abu Bakar, N. B., \& Abdul Rahman, A. (2007). A comparative study of zakah and modern taxation. J.KAU: Islamic Economics, 20(1), 25-40.

Ab Rahman, A., Alias, M. H., \& Syed Omar, S. M. N. (2012). Zakat institution in Malaysia: Problems and issues. GJAT, 2(10), 35-41.

Adamu, S. \& Saad, R. A. (2016). The impact of public governance quality, accountability and effectiveness on intention to pay zakat: Moderating effect of trust on zakat institutions. International Journal of Management Research \& Review, 6(1), 1-8.

Ahmed, H. (2004). Role of zakah and awqaf in poverty alleviation (Occasional Paper No. 8.).Jeddah: Islamic Research and Training Institute, Islamic Development Bank - IDB.

Akanni, A. A. (2006). Profiling a model for the administration of zakat in a multi-religious society: The case of south-western Nigeria. Journal of Philosophy and Culture, 3(2), 129-150.

Ali, K. M. \& Saaid, A. E. (2016). Zakah for poverty alleviation: Evidence from Sudan (IRTI Working Paper No. WP/2016/11). Jeddah: Islamic Research and Training Institute.

Aliyu, S. U. R. (2002). An appraisal of the performance and predicaments of the Kano Zakah Foundation. Al-Ijtihad: The Journal of Islamization of Knowledge and Contemporary Issues, 3(1), 71-87.

Amuda, Y. J. (2013). Empowerment of Nigerian Muslim households through waqf, zakat, sadaqat and public funding. International Journal of Trade, Economics and Finance, 4(6), 419-424.

Ashafa, S. A. (2014). The administration of zakat in Lagos and Ogun states. Research on Humanities and Social Sciences, 4(21), 74-87.

Ayuniyyah, Q., Pramanik, A. H. Md Saad, N. \& Ariffin, M. I. (2018). Zakat for poverty alleviation and income reduction: West Java, Indonesia. Journal of Islamic Monetary Economics and Finance, 4(1), 85-100. 
Mustafa, Baita, \& Adhama $\mid$ Quantitative Economic Evaluation of Zakah-Poverty Nexus in Kano State, Nigeria

Chin, W. W. (1998). The partial least squares approach to structural equation modeling, In G. A. Marcoulides (Ed.), Modern Methods for Business Research (pp. 295-336). Mahwah, New Jersey: Laurence Erlbaum Associates.

Falk, R. F., \& Miller, N. B. (1992). A primer for soft modeling. Ohio: The University of Akron Press.

Hadejia, I. M. (2017, November 19). Nigeria and the Asian Tigers. Daily Trust, p. 40.

Ibrahim, S. M. (2015). Systematic zakat management and administration: A framework for Kano state, Nigeria. IJRDO - Journal of Applied Management Science, 1(8), 1-19.

Kano State Zakkah and Hubusi Commission (2004). Brief report for the year 1425 A.H./2004. Kano: Author.

Kano State Zakkah and Hubusi Commission (2006). Collections of Zakah from May 29, 2004 to May 29, 2006. Kano: Author.

Kano State Zakkah and Hubusi Commission (2010). The comprehensive achievements from inception to date $(2010=1431 A H)$. Kano: Author.

Kano State Zakkah and Hubusi Commission (2015). Zakah (cash) collected from individuals and corporate bodies in Kano state. Kano: Planning Research and Statistics Department, Kano State Zakkah and Hubusi Commission.

Kefeli, Z., Johari, F., Ahmad, N., Mohd Daud, S. N., \& Shah Zaidi, M. A. (2017). Factors affecting quality of life of medical assistance recipients of Zakat fund in Malaysia. International Journal of Economics, Management and Accounting, 25(1), 125-140.

Krejcie, R., \& Morgan, D. (1970). Determining sample size for research activities. Educational and Psychological Measurement, 30, 607-610.

Maidugu, A.S. (2002). Alleviating poverty using zakah resources: A schema for Shari'ah implementing states in Nigeria. Al-ljtihad: The Journal of Islamization of Knowledge and Contemporary Issues, 3(1), 3-19.

Muktar, B. (2017). An empirical study of education expenditure on human capital development in Kano state, Nigeria. (Unpublished Undergraduate Project). Yusuf Maitama Sule University, Kano- Nigeria.

Mustafa, D., \& Maiyaki, A. A. (2011). The economic significance of the zakah system: An exploratory analysis of its fiscal characteristics. Elixir Finance Journal, 36. Retrieved October 9, 2012, fromwww.elixirjournal.org. 
Mustafa, Baita, \& Adhama $\mid$ Quantitative Economic Evaluation of Zakah-Poverty Nexus in Kano State, Nigeria

Mustafa, D. A., \& Idris, M. (2015). The contributions of Islamic economic institutions to modern Nigeria. Journal of Islam in Nigeria, 1(1), 36-58.

Mustafa, D. A., \& Maiyaki, A. A. (2016). Synergising zakah and Islamic banking for economic empowerment of the Ummah, In Y. O. Imam, R. I. Adebayo \& A. I. Aliagan (Eds.), Dynamics of revealed knowledge and human sciences (pp. 90-108). Ibadan: Spectrum Books Ltd.

Mustafa, D., Sabiu, T. T., \& Bello, A.I. (2017a). Re-engineering the institutions of zakah and waqf for economic empowerment in Kano state, Nigeria. Northwest Journal of Social and Management Sciences, 1(1), 34-53.

Mustafa, D., Baita, A. J., Sabo, M., \& Adhama, H. D. (2017b). Zakah system for poverty alleviation in Kano state, Nigeria: Pilot study on the validity and reliability of survey instrument. Paper presented at The International Conference on Regional Economic Integration, Kano Nigeria.

Mustafa, D., Baita, A. J. \& Mamman, A. (2018). Zakah institution and poverty alleviation nexus in Kano state, Nigeria: A structural equation model approach. Abuja Journal of Economics and Allied Fields, 9(5), 156-171.

Nadzri, F. A. A., AbdRahman, R., \& Omar, N. (2012). Zakat and poverty alleviation: Roles of zakat institutions in Malaysia. International Journal of Arts and Commerce, 1(7), 61-72.

National Population Commission (2006). Population census. Abuja: Author.

Wali, H. N. (2013). Utilization of zakat and Islamic endowment funds for poverty reduction: A case study of Zakat and Hubusi Commission, Kano State-Nigeria. Journal of Economics and Sustainable Development, 4(8), 141-147.

Wedgwood, A., \& Sansom, K. (2003). Willingness-to-pay surveys - a streamlined approach: Guidance notes for small town water services. Water, Engineering and Development Centre (WEDC), Loughborough University.

Wooldridge, J. M. (2009). Introductory econometrics: A modern approach (fourth edition). South-western: CENGAGE Learning.

Zainal, H., Abu Bakar, A., \& Saad, R. A. (2016). Reputation, satisfaction of zakat distribution, and service quality as determinants of stakeholder trust in zakat institutions. International Journal of Economics and Financial Issues, 6, 72-76.

IJIEF: International Journal of Islamic Economics and Finance, 3(1), 21-50|48 
Mustafa, Baita, \& Adhama $\mid$ Quantitative Economic Evaluation of Zakah-Poverty Nexus in Kano State, Nigeria

Appendix I

Statistics about the Population of Study

\begin{tabular}{|c|c|c|c|c|}
\hline $\mathrm{S} / \mathrm{N}$ & LGA & Population Size & Number of Markets & Allocated Questionnaires \\
\hline 1. & Nassarawa & 596,669 & Small $=4$ & 120 \\
\hline 2. & Dala & 418,777 & $\operatorname{Big}=4$ & 220 \\
\hline 3. & Kano Municipal Council (KMC) & 365,525 & Big $=4$ and Small = 2 & 220 \\
\hline 4. & Ungogo & 369,657 & Small = 2 & 100 \\
\hline 5. & Gwale & 362,059 & Small = 4 & 120 \\
\hline 6. & Kumbotso & 295,979 & Big $=1$ and Small = 2 & 100 \\
\hline 7. & Tarauni & 221,367 & Big = 1 and Small = 2 & 100 \\
\hline \multirow[t]{2}{*}{8.} & Fagge & 198,828 & $\operatorname{Big}=4$ & 250 \\
\hline & Total & $2,828,861$ & $\begin{array}{c}\text { Big }=14 \\
\text { Small }=16\end{array}$ & 1230 \\
\hline
\end{tabular}

Source: National Population Commission (2006) and Authors' Compilation (2018).

Appendix II

Result of Robust Regression Estimates

\begin{tabular}{lcccc}
\hline Variables & Coefficients & $\begin{array}{c}\text { Robust Standard } \\
\text { error }\end{array}$ & t-stat & P-value \\
\hline Constant & 1.921 & 0.521 & 3.69 & 0.000 \\
Zakah awareness & 0.111 & 0.041 & 2.70 & 0.000 \\
Zakah payment & 0.386 & 0.077 & 4.98 & 0.007 \\
Zakah management & 0.211 & 0.051 & 4.12 & 0.000 \\
\hline & & & Prob (f- & Number of \\
& R-Square & F-statistics & statistics) & Observations \\
& 0.2205 & 27.36 & 0.000 & 862 \\
\hline
\end{tabular}

Source: Computed by the Authors (2018).

IJIEF: International Journal of Islamic Economics and Finance, 3(1), 21-50|49 
Mustafa, Baita, \& Adhama $\mid$ Quantitative Economic Evaluation of Zakah-Poverty Nexus in Kano State, Nigeria

Appendix III

Sample of Academic Works on Zakah Institution in Nigeria

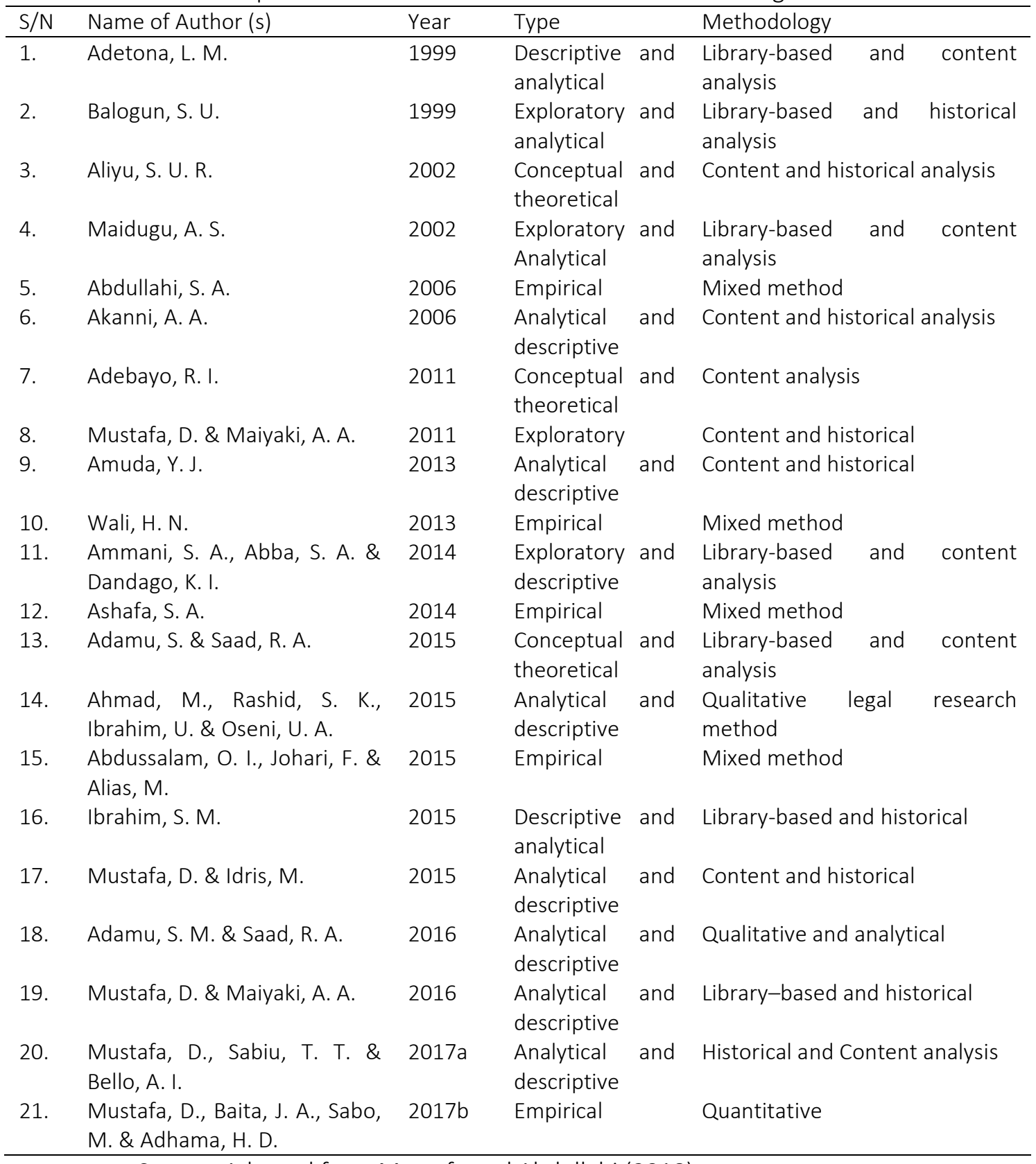

Source: Adapted from Mustafa and Abdullahi (2018).

IJIEF: International Journal of Islamic Economics and Finance, 3(1), 21-50|50 